\title{
Jednota, či rozmanitost? Kulturní cíle evropské audiovizuální politiky a jejich aplikace $v$ prostředí české televizní scény'
}

\author{
Unity or Diversity? Cultural objectives of the European audiovisual \\ policy and their implementation within the Czech television scene \\ Václav Štětka
}

\begin{abstract}
This paper examines the cultural objectives of the European Union's audiovisual policy, represented mainly by the Television without Frontiers Directive, and the practical outcomes of this policy in the Czech television landscape. In the first part, I briefly examine the presence and character of cultural objectives in the evolution of European broadcasting legislation. After that, I present and critically review the existing results of the program quota policy (contained in Articles 4 and 5 of the Directive) across Europe. The second part of the paper is devoted to an empirical case study of the implementation of the Television without Frontiers Directive in Czech media legislation, and particularly on the question of how Czech TV stations comply with the quotas on European and independent works and what kinds of cultural implications can be drawn from these results. In the final part, the current process of revision of the Television without Frontiers Directive is briefly explored, again with a focus on the way the new Audiovisual Media Services Directive reflects dominant conceptualizations of European culture and identity.
\end{abstract}

KEY WORDS Audiovisual Media Services Directive, cultural objectives, European audiovisual policy, European identity, Television without Frontiers, Unity in Diversity

V roce 2005 zveřejnila Evropská komise plán na inovaci legislativního rámce sektoru audiovizuálních médií. Tato inovace má mít podobu modernizace Směrnice Rady č. 89/552/ EHS o „Televizi bez hranic“, naposledy revidované před deseti lety (97/36/ES). Ve světle rychle postupujících technologických proměn oblasti audiovizuální produkce a distribuce, jež staví „tradiční“ televizní vysílání do jedné řady s mnoha jinými mediálními technologiemi schopnými přenášet audiovizuální obsahy, se Evropská komise rozhodla pro mnohem hlubší revizi než v roce 1997. Rozsah změny je možné vyčíst již z nového názvu tohoto hlavního regulačního nástroje pro oblast evropského audiovizuálního průmyslu, který má znít

Sociální studia. Fakulta sociálních studií Masarykovy univerzity, 3/2007. S. 61-87. ISSN 1214-813X.

1 Studie vychází z př́spěvku „Promoting Diversity, or Protecting National Culture? European Audiovisual Policy in the Context of the Czech Television Landscape“, prezentovaného na konferenci Comparing Media Systems: East Meets West v polském Kliczkowě 24. dubna 2007. 
„Směrnice o audiovizuálních mediálních službách“ (Audiovisual Media Services Directive), neformálně pak „Audiovizuální média bez hranic“ (Evropská unie 2007).

Není to nicméně pouze oblast mediálních technologií, co v současnosti prochází procesem transformace a co je potřeba vzít $\mathrm{v}$ úvahu při diskuzích o novém regulačním rámci evropské audiovizuální politiky. Proměnami - zřejmě nejzásadnějšími od podpisu Maastrichtské smlouvy v roce 1992 - prochází v současné době i samotná Evropská unie (viz Fiala 2007). Jejich zdrojem přitom není pouze historicky bezprecedentní rozšírení EU, které tu za poslední tři roky vedlo ke zdvojnásobení počet členských států (v porovnání s rokem 1992) a přivedlo do sdíleného legislativního a institucionálního prostoru země s hlubokými sociálními, kulturními a ekonomickými rozdíly. ${ }^{2}$ Paralelní prŕíčnou zmíněných proměn je rovněž pokračující proces prohlubováni evropské integrace, vedoucí k posilování institucionálních struktur Evropské unie, přesouvání rozhodovacích kompetencí od národních států směrem k evropským orgánům, a tím - v očích řady pozorovatelů - k postupnému vytváření evropského „superstátu“. Prozatímním vyvrcholením těchto snah je návrh tzv. evropské ústavy, tedy smluvního dokumentu, který má za cíl zjednodušit stávající komplikovanou právní strukturu Evropské unie a nahradit množství dílčích smluv jedním dokumentem, zavádějícím současně některé symbolické i institucionální prvky, formující EU do podoby skutečného státního útvaru. Tento projekt byl, jak známo, pozastaven v důsledku odmítnutí návrhu Ústavy v referendech ve Francii a v Nizozemí v roce 2005, což bývá interpretováno jako výraz nesouhlasu s překotnou rychlostí a současně slabou legitimitou integračních procesů, řízených evropskými elitami, a prritom se stále více vymykajících možnostem efektivní demokratické kontroly ze strany občanů členských zemí (viz např́klad Fiala 2007: 101-112). Současně je idea prohlubování integrace, zosobněná v projektu evropské ústavy, zpochybňována poukazem na (prozatímní) neexistenci evropského „národa“ (ethnos), př́padně politického lidu (demos), jehož zájmy by tento dokument - a potažmo integrační projekt jako takový - reprezentoval. Formování takovéhoto evropského lidu zase naráží na problém chybějící evropské veřejné sféry, která by hrála zprostředkující úlohu mezi rovinou evropské politiky a individuálními i kolektivními politickými zájmy, ale také na řadu teoretických i praktických obtíží s vymezováním evropské kolektivní identity, která by měla evropské integraci poskytnout patřičnou podporu na symbolické i individuálně-psychologické rovině.

I s ohledem na skutečnost, že projekt evropské ústavy byl v souvislosti s nizozemským nee a francouzským non pouze dočasně pozastaven, nikoli zcela opuštěn, je zřejmé, že právě nyní - snad více než kdy jindy v historii sjednocování evropského kontinentu - si Evropa potřebuje ujasnit, na jakých principech by mělo být (př́padné) pokračování integračního procesu založeno, jakými hodnotami, vizemi a symboly by měla být sjednocená Evropa definována (vůči okolnímu světu, ve vztahu k problematice imigrace i z hlediska prrípadného dalšího rozšiřování; viz Delanty a Rumford 2005) či jakým zpơsobem lze dosáhnout překonání nebo přinejmenším zmenšení tzv. demokratického deficitu, kterým dle mnohých názo-

2 Jak upozorňují v této souvislosti Gerard Delanty a Chris Rumford, „setkání západoevropských, středoevropských a východoevropských zemí není pouhým setkáním odlišných zemí, ale také odlišné logiky sociální a systémové integrace, a s tím souvisejících cest k modernitě“ (Delanty a Rumford 2005: 46). 
rů rozhodovací procesy v rámci Evropské unie trpí (viz např́klad Bowman 2006). Všechny zmíněné otázky jsou přitom obzvláště relevantní ve vztahu k oblasti audiovizuálních médií, jejichž potenciál pro širření evropského povědomí, stimulaci evropské identity a budování evropského komunikačního prostoru je předmětem dnes již poměrně rozvinutého teoretického i empirického bádání (Bruter 2003, Kevin 2003, Peter a de Vreese 2004, Schlesinger a Fossum 2005).

Vedle zkoumání úlohy médií v procesech evropské integrace, soustředících se především na struktury pan-evropského mediálního průmyslu (napríklad Chalaby 2002) či mediální pokrytí celoevropských témat (Trenz 2004; Downey a Koenig 2006; Machill, Beiler a Fischer 2006), se pozornost zaměřuje také na analýzu evropské mediální politiky, kladoucí si za cíl napomoci výkonu výše uvedené role médií coby nástrojů integračního projektu prostřednictvím sady legislativně-regulačních opatření, ale i pomocí různých dotačních programů (Levy 2001, Wheeler 2004, Nenova 2007). ${ }^{3}$ Tento obecný výzkumný směr sleduje i předkládaná stat', která se věnuje analýze evropské audiovizuální politiky, reprezentované zejména stávající Směrnicí o Televizi bez hranic, přičemž si všímá zvláště toho, do jaké míry a jakým způsobem tento legislativní nástroj artikuluje otázky evropské kultury a identity. První část stati stručně rekapituluje význam kulturních cílů ve vývoji evropské legislativy týkající se televizního vysílání. Následně se text zabývá prezentací a kritickou reflexí dosavadních výsledků politiky programových kvót, definovaných v článcích 4 a 5 Směrnice o Televizi bez hranic, které jsou obecně považovány za hlavní nástroj kulturní politiky EU v mediální sféře. $V$ druhé části př́spěvku je prezentována př́padová studie implementace obou dotyčných článků Směrnice do české mediální legislativy a její konkrétní výsledky v podobě statistik naplňování daných kvót hlavními českými televizními stanicemi; tyto statistiky jsou poté konfrontovány s údaji z analýzy sledovanosti, poskytující podrobnější informace o aktuálních programových preferencích českého televizního publika.

V samotném závěru se pak stat' stručně věnuje kulturně-politickým aspektům návrhu nové Směrnice o audiovizuálních mediálních službách, respektive otázce, jaké cíle v oblasti ochrany a budování evropské kultury a identity si nová legislativa klade.

\section{Evropská integrace a koncepce evropského sebepojetí}

Problematika kultury a identity byla teprve relativně nedávno uznána jako plnohodnotná - či dokonce nepominutelná - součást procesu evropské integrace. Podle Gerarda Delantyho (2000: 109-110) je posun ke kulturním aspektům integrace (ve smyslu kultury jako symbolického repertoáru pro tvorbu kolektivních identit a politických loajalit) charakteristický pro post-Maastrichtskou fázi integračního procesu, která následuje po počáteční fázi ekonomické spolupráce a budování společného evropského trhu (což bylo hlavním cílem Římských smluv z roku 1957) a následné fáze, kdy se prioritou stala politická integrace (zpočátku chápané pouze jako administrativní a legislativní sbližování členských států). Historii sjednocování Evropy, vedoucí od Evropského hospodářského společenství (EHS)

Nejvýznamnějším dotačním programem EU v oblasti audiovizuální tvorby je program na podporu audiovizuální produkce a distribuce (MEDIA), ustavený již v roce 1990. 
přes Evropské společenství (ES) až k Evropské unii (EU) je podle Delantyho rovněž možno popsat jako pozvolnou tranzici od „mělkého“ směrem k ,hlubšímu“ integračnímu projektu; tranzici, jež postupně vyzdvihla do popředí otázky evropské kultury a identity. ${ }^{4}$

Jak poznamenává Phillip Schlesinger, od podpisu Smlouvy o Evropské unii, tzv. Maastrichtské smlouvy, v roce 1992 začaly být kompetence v kulturních záležitostech ,„plně uznávanou součástí pravomocí Evropské unie“ (Schlesinger 1997: 371). Tato smlouva nejen že ustanovila samotnou kategorii evropského občanství (Článek 8), jež může být sama o sobě chápána $\mathrm{v}$ kulturních pojmech, ale specificky formulovala oficiální cíle evropské kulturní politiky, když v prvním odstavci Článku 128 uvádí, že „Společenství přispívá k rozkvětu kultur členských států a přitom respektuje jejich národní a regionální různorodosti a zároveň zdůrazňuje společné kulturní dědictví“ (Evropská unie 1992).

Text tohoto článku je velmi ilustrativní, nebot’ odkazuje k jednomu z klíčových problémů kulturních aspektů evropské integrace, konkrétně k napětí mezi jednotnou a plurální koncepcí Evropy a evropské identity. Citovaný článek Smlouvy o Evropské unii zřetelně uznává evropskou kulturní rozmanitost, tvořenou kulturami jednotlivých členských států, ale současně zdůrazňuje předpokládanou existenci sdíleného evropského kulturního dědictví, které by mělo být odhalováno a opatrováno. Jak se pokusím dokumentovat $\mathrm{v}$ tomto př́spěvku, tato nejednoznačnost (až rozpolcenost) týkající se toho, zda propagovat společné kulturní charakteristiky, či zda oslavovat evropskou kulturní rozmanitost, se promítá i do vývoje evropské audiovizuální politiky.

Obdobnou dualitu popisuje Monica Sassatelliová (2002) ve své reflexi několika soupeřících konceptualizací Evropy. První z nich, jež je v podstatě federalistickou koncepcí, chápe Evropu jako Jednotu (Unity) a je zakotvena ve víre ve společné duchovní a filozofické tradice, sdílené po celém kontinentu; tradice, které našly své nejvýraznější projevy v osvícenském projektu a v institucích modernity. Ve světle všudypřítomné kulturní globalizace potřebuje Evropa definovat to, co ji odlišuje od zbytku světa, a najít sama pro sebe místo jakožto ,jednotný subjekt" v rámci stále komplexnějšího a propojenějšího světa (Sassatelli 2002: 438).

Druhým typem evropské sebedefinice je Evropa jako Rozmanitost (Diversity). Ta je popisována Sassateliovou (2002: 438-439) jako „radikální kritika“ předchozího modelu evropské Jednoty, která se - po vzoru moderního nacionalismu - pokouší najít ke vznikajícímu evropskému superstátu odpovídající kulturu. ${ }^{5}$ Pokus budovat projekt evropské integrace na bázi společné kultury je odmítnut jako potenciální ohrožení stávající kulturní mnohosti, která dodává Evropě její zvláštní charakter; namísto toho jsou navrhovány jiné formy solidarity - např́íklad solidarity opírající se o ideu sociální smlouvy.

$4 \quad$ Fakt, že význam kultury a kulturních identit pro budování jednotné Evropy byl v počátcích integračního procesu opomíjen, dobře dokumentuje výrok připisovaný duchovnímu otci a architektovi evropského společenství Jeanu Monnetovi: „Pokud bychom měli začít budovat evropské společenství znovu, měli bychom začít s kulturou“ (cit. dle Collins 2002: 45). Richard Collins ovšem uvádí, že navzdory vysoké frekvenci, se kterou je daný výrok v současnosti citován, se jemu samotnému nepodařilo najít pramen, který by Monnetovo autorství potvrzoval (Collins 2002: 40).

5 Podle Collinse je supranacionalistická vize Evropské unie založena na (nacionalistickém) přesvědčení, že „politická obec a identita se musejí shodovat, pokud mají být státy legitimní a silné“ (Collins 2002: 26). 
Vedle těchto (vzájemně se vylučujících) koncepcí se podle Sassatelliové vynořuje třetí možnost, založená na dialektické kombinaci předchozích dvou modelů. Tento třetí typ, označovaný známým sloganem Jednota v Rozmanitosti (Unity in Diversity), je založen na uznání kolektivní identity jako mnohovrstevnatého konceptu, který umožňuje člověku být součástí různých kolektivit najednou, přičemž mu přiznává schopnost „přepínat“ mezi různými „,vrstvami loajality“, aniž by musel upřednostňovat některou z nich proti ostatním. $Z$ pohledu zastánců této vize Evropy její jednota „spočívá v dialogickém charakteru, tedy v kombinaci rozdílností, které nejsou homogenizovány“ (Sassatelli 2002: 439). Gerard Delanty a Chris Rumford hovoří o konceptu Jednoty v Rozmanitosti jako o „nové ideologii kultury“, která se vynořila v Evropě koncem 20. století ${ }^{6}$ a která „,perfektně zachycuje kulturní logiku evropeizace. Současně vyjadřuje politický duch doby - být rovnoprávný, ale odlišný“ (Delanty a Rumford 2005: 60). Podle autorů tento výraz sice ,postrádá filozofickou hloubku, ale v situaci obecné krize ostatních definic Evropy se mu dostává širokého kulturního ohlasu“, takže o něm lze hovořit jako o „,v současnosti nejvlivnějším výrazu evropské identity“ (Delanty a Rumford 2005: 56). Také Sassatelliová uvádí, že navzdory často ne právě pozitivnímu hodnocení tohoto konceptu, kritizovaného za př́lišnou nejednoznačnost či neodůvodněný idealismus (předpokládající přirozeně harmonickou koexistenci rozdílných vrstev identity a loajality), právě tento typ kulturní sebedefinice „dominuje nejen v současných akademických př́istupech, ale také [...] v oficiálních diskurzech a politikách EU“ (Sassatelli 2002: 438). Oblibu tohoto konceptu je těžko možné demonstrovat lépe než tím, že Evropská unie si zvolila Unity in Diversity jako svoje oficiální motto, což podle Sassatelliové umožnilo EU „vyhnout se naplnění myšlenky evropského kulturního korpusu konkrétními prvky“ (Sassatelli 2002: 438). Do jaké míry tento krok odráží upřímné přesvědčení orgánů EU o kulturním charakteru Evropy, z principu znemožňujícím takový korpus sestavit, a do jaké míry může být uvedený slogan chápán spíše jako „rétorická eskamotáž, jejímž účelem je zakrýt v podstatě centralizační ,top-down' př́stup“ (Shore 2000, cit. dle Sassatelli 2002: 441), to je otázka pro jinou debatu. V této studii se nebudeme snažit odhalit motivaci evropských činitelů pro propagaci toho či onoho konceptu, ale hodláme zkoumat, zda a jakým způsobem jsou výše nastíněné modely evropské identity reflektovány v diskurzu evropské audiovizuální politiky.

6 Podle Delantyho s Rumfordem představuje Jednota v Rozmanitosti „unikátní evropský diskurz“ (ačkoli jej používal např́íklad již Jawaharlal Nehru pro definici indické národní identity a z pohledu politické filozofie může být jeho geneze sledována až k romantickému nacionalismu 19. století), který v průběhu 90. let nahradil do té doby dominantní „liberální étos evropské integrace“, charakterizovaný tolerancí národních kultur, které byly evropeizací víceméně nedotknuty. Tento étos se podle autorů začal vytrácet se sílící politickou integrací EU, která „od Maastrichtu (1992) předávala stále více moci superstátu, který již dále nemohl být vnímán v liberálním pojetí“ (Delanty a Rumford 2005: 59). K uvedenému „obratu k rozmanitosti“" v rámci oficiální koncepce evropské identity přispěla dále v 90 . letech řada externích vlivů, jako např́iklad vlivný dokument UNESCO „Our Creative Diversity“ (1995), jenž obhajoval velmi relativistické pojetí kultury; dále vývoj v oblasti koncepce lidských práv (směřující k uznání práv kulturních); rozmach postmoderního myšlení; či procesy globalizace, ustavující multipolární a multicentrický světový rád. 


\section{Kultura, identita a geneze evropské audiovizuální politiky}

Jak poznamenává Mira Nenovová (2007: 4), ačkoli televizní vysílání „původně nepatřilo mezi oblasti regulačních aktivit Evropského společenství a nebylo explicitně zmiňováno v Římských smlouvách z roku 1957, nýbrž až ve Smlouvě o Evropské unii (Maastrichtské smlouvě) z roku 1992, ${ }^{7}$ neznamená to, že Evropské společenství nevěnovalo před rokem 1992 této oblasti žádnou pozornost. Byl to ovšem Evropský parlament, nikoli Evropská komise, který v rámci Společenství vyvinul v této oblasti první aktivity, když v roce 1982 přijal Rezoluci o rozhlasovém a televizním vysílání v Evropském společenství (založené na takzvané Hahnově zprávě). Kromě obecného varování před deregulací vysílání a výhrad proti komercializaci informací (viz Collins 2002) tato rezoluce zmínila potřebu zaměřit se na evropskou kulturu a evropské povědomí, přičemž právě informační média označila jako prostředky sloužící k utváření evropské identity a vlastní tok informací jako „možná rozhodující faktor evropské integrace“. 8

Evropská komise učinila první krok k regulaci televizního vysílání v roce 1984 v rámci koncepčního materiálu s názvem „Zelená kniha o ustanovení jednotného trhu v oblasti televizního vysíláni““, ${ }^{9}$ která podle Nenovové (2007: 5) představovala vlastní počátek audiovizuální mediální politiky Evropského společenství a může být pokládána za př́mého předchůdce Směrnice o Televizi bez hranic (Television without Frontiers Directive, dále jen Směrnice TWF). Tento dokument volal po vybudování jednotného evropského audiovizuálního prostoru, což bylo zdůvodňováno nutností přispět - prostřednictvím sdílení televizních programů - $\mathrm{k}$ podpoře užších vztahů mezi evropskými národy a $\mathrm{k}$ budování evropské identity. Televize byla chápána jako nástroj tvorby a kultivace povědomí o bohatství a rozmanitosti evropského kulturního dědictví a také jako nástroj propagace „společného osudu“ v rámci sjednocení Evropy. Konstrukce silného evropského audiovizuálního průmyslu, což byl evidentně hlavní cíl plánované politiky, měl pomoci Evropanům „ochraňovat jejich kulturní identitu“ a živit „naději na ekonomický rozvoj ve světle americké a japonské expanze“ (cit. dle Schlesinger 1991: 140).

V tzv. Maastrichtské smlouvě je audiovizuální sektor specificky zmiňován ve druhém bodě článku 128, který uvádí, že „činnost Společenství je zaměřena na povzbuzování spolupráce mezi členskými státy a v př́padě potřeby na podporu a doplňování jejich činnosti v následujících oblastech:

- zlepšování znalosti a šíření kultury a dějin evropských národů,

- zachování a ochrana kulturního dědictví evropského významu,

- nekomerční kulturní výměny,

- umělecké a literární tvorby, včetně tvorby v audiovizuální oblasti“ (Evropská unie 1992).

8 V Hahnově zprávě je formulována explicitní, dokonce kauzální vazba mezi informačními médii, tvorbou evropské identity a úspěchem integračního projektu: „[...] sjednocení Evropy bude dosaženo jedině tehdy, pokud si to budou Evropané přát. Evropané si to budou prrát pouze tehdy, jestliže bude existovat taková věc jako evropská identita. Evropská identita se vyvine pouze za předpokladu, že budou Evropané adekvátně informováni. V současné době jsou informace přenášené masovými médii kontrolovány na národní úrovni [...]““(cit. dle Collins 2002: 29).

9 V originále Television without Frontiers: Green Paper on the Establishment of the Common Market for Broadcasting, Especially by Satellite and Cable. 
Také rhodeský summit Evropské rady v roce 1988, který požadoval „zesílit úsilí“ a ,zrychlit práci“ při př́ípravě Směrnice TWF, vyjádřil své přesvědčení, že iniciativy v oblasti evropské audiovizuální politiky vedoucí ke „,vzniku vskutku evropského audiovizuálního trhu... přispějí k podstatnému posílení evropské kulturní identity“ (Evropská unie 1988).

Je zřjejmé, že v těchto počátečních aktivitách v oblasti evropské audiovizuální politiky, explicitně zmiňujících budování evropské identity a propagaci evropského kulturního dědictví jako jedny ze svých hlavních cílů, se odráží diskurz Evropy jako Jednoty. Ze zmíněných politických cílů, které se s tímto diskurzem obecně shodují, však byla jen menší část zahrnuta do recitálů Směrnice TWF (přijaté v roce 1989, s účinností od roku 1991), jež představuje „primární regulační nástroj Evropské unie pro audiovizuální média“ (Nenova 2007: 5). ${ }^{10}$ I když Směrnice TWF (Evropská unie 1989) ve svém prvním recitálu zopakovala cíl vytváření „stále užšího svazku“ (an ever closer union) mezi členskými státy, obsažený již v textu Ř́mských smluv, z obsahu směrnice je zřjejmé, že tento cíl nechápe primárně v kulturním smyslu. Většina komentátorů z řad akademické obce se shoduje v tom, že kulturní cíle představují „méně významný prvek směrnice“ a že její jádro tvoří ekonomické a průmyslové důvody, především pak „odstranění překážek zamezujících svobodnému pohybu služeb“ a „zabezpečení toho, aby na společném trhu nebyla narušována soutěž“ (David Graham and Assoc. Ltd. 2005: 76). Opatření týkající se kulturních cílů jsou víceméně implicitní; evropská identita či evropské povědomí nejsou zmíněny vůbec. Prakticky jediným místem v celém textu Směrnice TWF, které se specificky zmiňuje o kulturních cílech, je recitál 13, zaručující, že opatření směrnice neovlivňují „nezávislost kulturního vývoje v členských státech a ochranu kulturní rozmanitosti ve Společenství “ - což může být chápáno jako výraz posunu od konceptu „Evropa jako Jednota“ směrem k „Jednotě v Rozmanitosti“. Není přitom zřejmé, jakou konkrétní kulturní politiku reflektují známé a široce diskutované články 4 a 5 Směrnice TWF, jež jsou obvykle chápány jako její hlavní kulturní opatření, nebot' požadují, aby vysílatelé vyhradili ,pro evropská díla většinový podíl svého vysílacího času“a ,nejméně 10 \% svého vysílacího času [...] nebo alternativně podle výběru členského státu nejméně $10 \%$ svého programového rozpočtu pro evropská díla vytvořená výrobci nezávislými na subjektech televizního vysílání“ (Evropská unie 1989).

Jak je často uváděno, ambivalentní pojetí kulturních cílů v rámci Směrnice TWF, která je jinak chápána povýtce jako nástroj liberalizace (Wheeler 2004), jakkoli obsahuje řadu restriktivních opatření (jako právě výše zmíněné obsahové kvóty), je z velké části produktem soupeření mezi tím, co Richard Collins (2002) nazývá „rivalitní paradigmata“ v rámci audiovizuální politiky Evropského společenství. Tento paradigmatický spor, který je většinou popisován jako konflikt mezi ,liberály/deregulátory“, jejichž motivace jsou povětšinou ekonomické (vytvoření jednotného audiovizuálního trhu), a „dirigisty“, resp. stoupenci

10 V originále Directive 89/552/EEC of 3 October 1989 on the Coordination of Certain Provisions Laid Down by Law, Regulation or Administrative Action in Member States Concerning the Pursuit of Television Broadcasting Activities. Kromě zavedení kvót na evropskou a nezávislou tvorbu, kterým se tento př́spěvek věnuje podrobněji, Směrnice TWF z roku 1989 harmonizovala regulaci televizního vysílání zejména v oblasti pravidel vysílání reklamy a sponzornigu a v oblasti pravidel na ochranu mládeže před škodlivým a nežádoucím obsahem (O’Connell 1996). 
intervencionismu, snažícími se prosazovat $\mathrm{v}$ rámci evropské mediální legislativy rovněž kulturní cíle, nerozdělují přitom pouze Evropskou komisi a Evropský parlament, ale také jednotlivá Generální ředitelství Evropské komise samotné (Collins 2002: 14). To v důsledcích znamená, že mnohé produkty legislativního procesu mají podobu určitého kompromisu (jehož konkrétní podoba samozřejmě závisí na momentálním poměru sil mezi uvedenými stranami); př́íladem toho může být právě formulace požadavků na dodržování programových kvót v článcích 4 a 5 Směrnice TWF. Oba tyto články obsahují (nechvalně) známou vsuvku „tam, kde je to možné" (where practicable), která umožňuje vysílatelům poměrně pohodlně kvótní limity ignorovat, pokud mohou hodnověrně prokázat, že nejsou schopni je naplňovat.

Nicméně ani v rámci dirigisticko-intervencionistického „tábora“ nelze zřejmě hovořit o jednotné či neměnné představě o cílech kulturní politiky a prostředcích, jakými by jich mělo být dosahováno. $Z$ pohledu tohoto prríspěvku je přitom podstatný fakt, že proměny těchto představ zřetelně korespondují s výše popisovanými proměnami konceptualizace evropské identity. Jak uvádí David Levy, „prvotní důraz na roli audiovizuální politiky při utváření evropské identity neměl dlouhého trváni'“, posunujíc se v průběhu 80. let stále více směrem k požadavku uchovávání existující kulturní rozmanitosti, chápané převážně coby rozmanitost národních kultur (Levy 2001: 42). Podle Collinse (2002) tvůrci evropské politiky postupně nahradili úmysl vytvořit evropskou kulturu starostí o roli médií v uchovávání existující evropské kulturní rozmanitosti. „Duch“ Hahnovy zprávy (a do určité míry i Zelené knihy z roku 1984) se do značné míry vytratil na konci osmdesátých let, a „argumenty, které dirigisté snášeli ve prospěch regulace a intervence, začaly prosazovat evropskou kulturní rozmanitost spíše než evropskou a kulturní jednotu“ (Collins 2002: 16).

\section{„Prime-time patrí národu, day-time patrí Americe“: A co zbývá na Evropu?}

V Sedmém sdělení o uplatňování článků 4 a 5 směrnice 89/552/EHS (Evropská unie 2006b), které porovnává a hodnotí údaje o naplňování programových kvót $\mathrm{v}$ jednotlivých členských zemích v letech 2003-2004, vyjádřila Komise obecnou spokojenost jak se stavem evropského televizního průmyslu (hodnoceného počtem nově vzniklých televizních stanic), tak s výsledky národních aplikací kvótní politiky. Podle Komise se „cíle článků 4 a 5 směrnice ,Televize bez hranic'stejně jako v předchozích obdobích bez potíží plní i ve stávajícím referenčním období (2003-2004), a to jak na evropské úrovni, tak na úrovni členských států, včetně deseti z nich, které k EU přistoupily v roce 2004“" (Evropská unie 2006b: 8). Toto hodnocení je založeno na kombinaci několika dílčích výsledků. Pokud jde o evropská díla, v roce 2004 činil průměrný vysílací čas vyhrazený evropským dílům na všech kanálech, které spadají pod definici uvedenou ve Směrnici, 63,3 \%, což představuje mírný pokles oproti předchozímu roku (65,2 \%). Přesto tato hodnota podle Komise dokládá „všeobecně řádné uplatňování článku 4 v rámci EU“ (Evropská unie 2006b: 5). ${ }^{11}$ Průměrná míra splnění požadavku

11 Na úrovni jednotlivých členských států se průměrný vysílací čas vyhrazený evropským dílům pohyboval od 52,8 \% (Irsko) a 86,2 \% (Dánsko) v roce 2003 a mezi 49,1 \% (Česká republika) a 86,3 \% (Dánsko) v roce 2004 (Evropská unie 2006b). 
na většinový podíl evropských děl (tzv. compliance rate) dosáhla 72,8 \% v roce 2004, což je o 4,6 procentního bodu více než v roce $2003 ;{ }^{12}$ to znamená, že tři ze čtyř evropských stanic překročily povinný 50\% limit. Pokud jde o evropská díla vytvořená nezávislými producenty, průměrný podíl jejich vysílacího času ve všech členských státech činil 31,5 \% v roce 2004, tedy zřetelně více než požadovaný 10\% limit. Průměrná míra splnění (compliance rate) vzrostla ze 78,4 \% v roce 2003 na $81,9 \%$ v roce 2004 .

Otočíme-li ovšem hodnotící optiku „,naruby“, lze říci, že v roce 2004 každá čtvrtá televizní stanice v EU nenaplňovala požadavek 50 \% podílu evropských děl (a každá pátá nesplnila limit $10 \%$ podílu děl od nezávislých producentů). Navzdory tomu je hodnocení Komise veskrze optimistické, poukazující na uspokojivý „střednědobý trend“ týkající se proporce evropských děl, ${ }^{13}$ zvláště pokud statistiky ukazují, že nové členské státy dosáhly co do naplňování kvót srovnatelných výsledků se „starými“ členskými zeměmi. ${ }^{14}$

Je nicméně zřejmé, že ke skutečnému posouzení efektů článků 4 a 5 Směrnice TWF tato zjednodušená matematická perspektiva nemůže postačovat. Jak ukazují výsledky nezávislé studie vypracované na zadání Evropské komise konsorciem David Graham and Associated Limited (2005), prosté aritmetické průměry poukazující na podíly evropských a nezávislých děl zakrývají řadu jiných významných údajů a problematických skutečností, které by celkové hodnocení kulturních cílů Směrnice mělo brát v úvahu.

Prvním problematickým bodem, obsaženým ostatně již v citovaném Sedmém sdělení Komise Evropskému parlamentu (Evropská unie 2006b), jsou poměrně slabé výsledky v prosazování účinnosti kvótních požadavků ze strany národních regulačních orgánů. V doplňujícím materiálu ke zmíněnému Sedmému sdělení (Evropská unie 2006c) Komise uvádí, že regulační orgány v členských státech nepřijímají žádná opatření v situacích, kdy televizní vysílatelé v daných zemích zjevně nenaplňují kvótní limity:

Členské státy informovaly o různých typech opatření: pokračující dialog, dohled nad dotyčnými stanicemi, formální upozornění a další sankce proti vysílatelům, které mohou vyústit v pokuty nebo až v odebrání licence. Jen v několika málo př́padech byla nicméně daná opatření skutečně uplatněna. (Evropská unie 2006c: 20)

Jak citovaná studie zjistila v průzkumu mezi evropskými vysílateli a producenty, většina z nich nevěří, že články 4 a 5 jsou striktně monitorovány, případně že dochází k uplatňování sankcí proti těm, kteří kvóty nenaplňují. Podle této studie je 59 \% vysílatelů a 79 \% producentů přesvědčeno, že nikdy nedochází k uplatnění sankcí. Další odpovědi z uvedeného

12 Průměrná míra splnění požadavku (compliance rate) na většinový podíl evropských děl se pohybovala od $50 \%$ (Belgie a Irsko) do $100 \%$ (Finsko) v roce 2003 a od $45 \%$ (Velká Británie) do $100 \%$ (Estonsko, Lotyšsko, Malta a Slovensko) v roce 2004 (Evropská unie 2006b).

13 Podíl evropské tvorby se v celoevropském průměru na konci 90 . let stabilizoval nad hranicí $60 \%$ z celkového vysílacího času (Evropská unie 2006b).

14 Nové členské státy vykazovaly v období mezi 1. květnem a 31. prosincem 2004 průměrný podíl 61,8 \% evropské tvorby v celkovém vysílacím čase (Evropská unie 2006b). 
průzkumu pak dokládají, že ,jen 26 procent vysílatelů a $10 \%$ producentů věří, že sankce jsou efektivním nástrojem k dodržování požadavků obsažených v článcích 4 a 5“ (David Graham and Assoc. Ltd. 2005: 169). Je zřejmé, že tyto výsledky otevírají prostor pochybnostem o efektivitě těchto regulačních opatření, stejně jako o jejich reálném vlivu na rozhodování vysílatelů o skladbě programových schémat.

Druhý závažný nedostatek politiky programových kvót v rámci Směrnice TWF spočívá v tom, že tento dokument ve své definici „evropské tvorby“ nerozlišuje mezi domácími a zahraničními programy. Tato všeobecná definice $\mathrm{v}$ důsledku umožňuje provozovatelům vysílání naplňovat požadavky článku 4 , aniž by přitom byli nuceni zařadit do programu jediný pořad z jiné evropské země. Tento (teoretický) př́klad přitom není př́liš vzdálen realitě současného evropského televizního trhu. Jak zmíněná nezávislá studie ukazuje, průměrný podíl vysílacího času věnovaného např́ic EU zahraničním dílům evropského původu činil v roce 2002 pouhých 12,3\%; oproti roku 1999, kdy byl tento podíl 13,9 procent, se navíc jedná o mírný pokles (David Graham and Assoc. Ltd. 2005: 183). Tento údaj očividně snižuje očekávání týkající se pěstování evropské kulturní identity prostřednictvím vzájemné výměny televizních programů mezi jednotlivými státy EU a potvrzuje názor, že navzdory odstranění technických a legislativních bariér pro přsshraniční televizi, v čemž Směrnice nepochybně uspěla, zůstávají kulturní a jazykové bariéry, rozdělující Evropu, stále velmi silným faktorem determinujícím divácké preference. Aktuální údaje shromážděné Evropskou audiovizuální observatoří (European Audiovisual Observatory, EAO) dále podtrhují tento trend, když dokládají „značný ústup koprodukci“" mezi jednotlivými evropskými státy za několik posledních let, vedoucí k tomu, že evropská fikce „se stává více domácí a lokální než kdy předtím“, což je „poněkud paradoxní v ére globalizace a interkulturality“ (EAO 2005: 65). ${ }^{15}$

Neméně významný - z kulturní i čistě ekonomické perspektivy - se zdá být fakt, že jediné programy, které jsou permanentně schopné překračovat evropské hranice, pocházejí z USA. To jistě není nový fenomén; naopak, lze jej dokumentovat v průběhu 80 . i 90 . let (Silj 1989, De Bens a de Smaele 2001, Tunstall a Machin 1999). Je však užitečné připomenout, že to byla právě vzrůstající neschopnost evropských filmových a televizních producentů soupeřit s americkými filmy a mýdlovými operami, která tvořila jeden z hlavních argumentů tábora dirigistů/intervencionistů pro zavedení kvótní politiky před osmnácti lety. Fakt, že Spojené státy i dnes zaujímají pozici dominantního exportéra audiovizuálních obsahů naprríč evropskými mediálními trhy (EAO 2005: 65) a že deficit importu a exportu audiovizuálních produktů mezi EU a USA stále narůstá (v roce 2002 činil 1,75 miliardy euro; David Graham and Assoc. Ltd. 2005: 10), představuje třetí ze sady nedostatků, které jsou v „oficiálním“ hodnocení efektivity Směrnice TWF zakrývány. Ačkoliv podíl amerických zábavních pořadů na evropských obrazovkách v poslední době poklesl (ze 71,8 \% celkového importu v roce 1998 na 62,4 \% v roce 2004 na pěti největších evropských trzích; EAO 2005: 94), tento trend je vyvažován paralelním nárůstem mezinárodní koprodukce, jejíž podíl stoupl z 3,1 \% v roce 1998 na 13,4 \% v roce 2004 (EAO 2005: 94). ${ }^{16}$

Podle Evropské audiovizuální observatoře „např́iklad v obou anglosaských zemích existuje téměř naprostá rezistence vůči evropským importům“ (EAO 2005: 66).

16 Jak Evropská audiovizuální observatoř poznamenává, „i když tyto [koprodukce] někdy zahrnují 
Na úsvitu éry nové audiovizuální politiky tak Evropská audiovizuální observatoř charakterizuje situaci na evropském televizním trhu zkratkou ,„prime-time [hlavní vysílací čas] patří národu, day-time [programová okna mimo hlavní vysílací čas] patří Americe“ (EAO 2005: 66). Programy z ostatních evropských zemí jsou většinou u evropských diváků v pozici „třetí volby“ (Collins 2002: 32). A ačkoliv má podíl evropské fikce v posledních letech vzrůstající tendenci (měřeno vysílacím časem), hodnota tohoto ukazatele je snižována paralelním poklesem jednotlivých titulů. To znamená, že jednotlivé seriály mají stále více dílů, jejichž vysílací čas se nicméně zkracuje, kterýžto trend EAO charakterizuje jako „stále více toho samého“ (EAO 2005: 65).

Při pohledu na výše uvedené statistiky tedy není překvapením, že většina komentátorů z akademické obce hodnotí naplňování kulturních záměrů Směrnice TWF kriticky. Mira Burri Nenovová např́klad uvádí, že Směrnice TWF , pro dosažení kulturních cílů mnoho neučinila“, a naopak ji lze charakterizovat jako „vítězství komerčních sil a těch, kteří prosazovali anti-protekcionistickou politiku“ (Nenova 2007: 9). Podle Marca Chalabyho politické iniciativy typu Směrnice TWF ,nedokázaly zastavit příliv amerických materiálů a v některých prŕpadech se dokonce ukázaly jako kontraproduktivní“; namísto napomáhání rozvoji evropské filmové a televizní tvorby Směrnice TWF ,poskytla Hollywoodu široký trh a množství nových klientů, dychtivých naplnit programové hodiny levným televizním materiálem“ (Chalaby 2006: 48). Richard Collins si všímá selhání jak ekonomických, tak kulturních cílů; podle něj ,sjednocený vysílací trh nejenže nevylepšil soutěžní pozici evropských audiovizuálních producentů tím, že jim poskytl domácí trh srovnatelný s trhem USA, ale ani nepřipoutal evropské televizní diváky ke společné kultuře, propagující Evropskou unii“ (Collins 2002: 19).

Pokud bychom měli Směrnici TWF hodnotit z hlediska tří kulturních koncepcí Evropy nastíněných v první části př́spěvku, je zřejmé, že ani formulace cílů směrnice, ani její praktické výsledky nepodporují model „Evropa jako Jednota“. Je nicméně rovněž otázkou, zdali můžeme $-\mathrm{v}$ souladu $\mathrm{s}$ aktuálně prosazovanou podobou evropského sebepojetí - v př́padě Směrnice TWF hovořit o modelu „Jednota v Rozmanitosti“. Nebot’ odhlédneme-li od čistě technických opatření, harmonizujících do jisté míry různorodé národní mediální legislativy, je obtížné rozpoznat jakoukoli jinou Jednotu, která by mohla být obsažena at' už v textu Směrnice, anebo v současném dění na evropské televizní scéně. Evropa zůstává hluboce rozdělena a fragmentarizována; národní státy si uchovávají postavení hlavních tvưrců regulačních rámců pro svá média a klíčových zprostředkovatelů kulturních identit pro svoje obyvatele. Revize Směrnice TWF z roku 1997 (Evropská unie 1997b) tento status quo nijak nenarušila, vezmeme-li v úvahu, že jedna z jejích hlavních inovací spočívala v zavedení článku 3a o ,událostech značného společenského významu“ (events of major importance for society). ${ }^{17}$

účast jiného evropského producenta, více než často jsou založeny na iniciativách severoamerických společností“ (EAO 2005: 94).

17 Tento článek uděluje členským státům pravomoc regulovat vysílání určitých událostí způsobem, který by zajistil, že z jejich sledování nebude vyloučena „významná část veřejnosti““ (significant 
Tento článek lze chápat jako další krok směrem pryč od konceptu Evropy jako Jednoty, nebot' je zaměřen na ochranu ,práva“ národních publik virtuálně se podílet na tom, co splňuje definici významné společenské události, prričemž z implementace tohoto článku $\mathrm{v}$ jednotlivých členských státech (viz Štětka 2003) vyplývá, že drtivá většina takto vymezených událostí má „pouze“ národní, nikoli evropský rozměr. V mediální teorii bychom přitom těžko našli lepší př́ílad mechanismu národní integrace v období pozdní modernity, než jaký představují právě tyto národně definované „mediální události“ (viz Dayan a Katz 1992).

\section{Televize bez hranic v ČR: Ve znamení liberálního přístupu}

Česká republika implementovala audiovizuální acquis communautaire, reprezentovaný Směrnicí TWF, do své národní legislativy v Zákoně o rozhlasovém a televizním vysílání z roku 2001 (dále jen vysílací zákon). Pokud jde o články 4 a 5, týkající se podílu evropské a nezávislé tvorby, čeští zákonodárci se - na rozdíl od řady jiných zemí ${ }^{18}$ - rozhodli pro téměř doslovnou transkripci textu směrnice, což znamená, že nezvolili možnost navýšení kvótních limitů či jiného zpř́snění obou článků, jak Směrnice TWF explicitně umožňuje. Vysílací zákon ukládá stanicím povinnost „tam, kde je to proveditelné, vyhradit pro evropská díla nadpoloviční podíl celkového vysílacího času každého svého programu“. ${ }^{19}$

V př́ípadě evropské nezávislé tvorby vysílací zákon rovněž kopíruje „originál“ Směrnice TWF, když požaduje po provozovatelích vysílání, aby věnovali minimálně $10 \%$ celkového vysílacího času anebo $10 \%$ programového rozpočtu programové tvorbě pocházející od nezávislých producentů. Také definice celkového vysílacího času, z něhož se počítá kvótní podíl, je shodná se Směrnicí TWF, takže vylučuje zpravodajství, sport, hry, reklamu, tele-

part of the public). Státy si mohou vytvořit oficiální seznam veřejných akcí, které jsou shledány společensky natolik významnými, že jejich televizní přenos musí být dostupný co nejširším vrstvám obyvatel daného státu, eo ipso na volně přistupných kanálech (Free-TV) s celostátním dosahem. Směrnice v této souvislosti uvádí sportovní akce jako Olympijské hry, Mistrovství světa či Evropy v kopané, avšak ponechává jednotlivým národním regulačním orgánům volnou ruku k rozhodnutí, zda je do svých seznamů zařadí či nikoliv; stejně tak je ponechána volnost k upřesnění formulace „významná část veřejnosti““ (viz Štětka 2003: 241-245).

18 Podle zprávy konsorcia David Graham and Assoc. Ltd. (2005: 95-96) přijalo šest „starých“ členských států EU - Finsko, Francie, Itálie, Nizozemí, Španělsko a Velká Británie - vyšší kvótní požadavky než ty, jež vymezuje Směrnice TWF. Bohužel citovaná zpráva zahrnuje pouze data ze „starých“ členských zemí EU (tj. EU 15), takže na porovnání s implementací dotyčných článků v „nových“ členských zemích - které by bylo z pohledu České republiky pravděpodobně ještě zajímavější - zde musíme prozatím rezignovat.

19 Země evropské patnáctky (tj. „staré“ členské země EU) se liší v tom, jestli zakomponovaly vsuvku „tam, kde je to proveditelné“ do své národní legislativy. Rakousko, Belgie, Lucembursko, Španělsko a Švédsko jsou mezi těmi státy, které tuto vsuvku zařadily, zatímco ostatní tak neučinily, čímž zvolily „méně flexibilní“ interpretaci článků 4 a 5 Směrnice. Některé státy (Rakousko, Belgie, Francie, Lucembursko a Španělsko) nicméně začlenily do své legislativy také „klauzuli o nesklouznutí“ (nonslipback clause), která rríká, že provozovatelé vysílání nemohou zařazovat menší podíl evropské tvorby než v předchozím roce (David Graham and Assoc. Ltd. 2005: 90). 
text a teleshopping. ${ }^{20}$ Jediné opatření, které zavádí český vysílací zákon nad rámec požadavků Směrnice TWF, se týká podílu „nové tvorby“ (tedy děl, „od jejichž prvního zveřejnění neuplynulo více než 5 let"), což tato směrnice ponechává bez specifikace (hovoří pouze o „přiměřeném podílu“), avšak vysílací zákon ho definuje jako $10 \%$ z vysílacího času nezávislých děl, nebo $10 \%$ z programového rozpočtu pro nezávislou tvorbu. Na rozdíl od většiny „starých“ členských zemí EU, které ukládají vysílateli povinnost vysílat určitý podíl programů v národním jazyce či v jazyce etnických menšin, Česká republika nevložila do vysílacího zákona žádné zvláštní jazykové nebo jiné „kulturni““ požadavky. ${ }^{21}$ Jediným paragrafem, který se explicitně zmiňuje o kultuře, je §17, který vyjmenovává určité skutečnosti důležité pro rozhodování o udělení vysílací licence, mezi nimi také „přínos žadatele k zajištění rozvoje kultury národnostních, etnických a jiných menšin v České Republice“, avšak nestanovuje žádná konkrétní kritéria, která by vysílatel musel splňovat. Zákon také nepožaduje po vysílatelích, aby finančně přispívali na vznik domácí televizní či filmové produkce, jako je tomu např́klad ve Francii, Rakousku či Finsku; ${ }^{22}$ pokus prrijmout zákon, který by tuto povinnost zavedl (a zř́́dil speciální fond na podporu kinematografie) byl v roce 2006 vetován prezidentem Václavem Klausem.

Celkově lze říci, že implementace článků 4 a 5 Směrnice do české legislativy je charakterizována poměrně liberálním př́stupem, který ponechává flexibilitu původního textu Směrnice, aniž ukládá vysílatelům nějaké další požadavky týkající se podpory evropských či nezávislých děl. V kontextu analytického modelu sestaveného autory nezávislé „Studie opatření týkajících se podpory distribuce a produkce televizních programư“ (David Graham and Assoc. Ltd. 2005) by tato forma implementace zřejmě umístila Českou republiku do společnosti Rakouska, Dánska, Německa či Irska, jejichž způsob implementace kombinuje flexibilní aplikaci Směrnice s nízkými dodatečnými požadavky na provozovatele vysílání, což ji staví do př́mého protikladu ke skupině států (Belgie, Finsko, Francie, Itálie, Portugalsko, Velká Británie), které zvolily preskriptivní aplikaci Směrnice a uplatňují na své domácí vysílatele dodatečné obsahové požadavky. ${ }^{23}$

20 Tuto definici zachovává většina ze zemí evropské patnáctky, kromě Francie, Německa, Itálie a Velké Británie, které přijaly př́ísnější definici vysílacího času, která vylučuje programy, jež jsou obvykle domácího původu, jako např́íklad talk show nebo publicistika (David Graham and Assoc. Ltd. 2005: 89).

21 Např́íklad v Řecku musí být $25 \%$ celkového vysílacího času vyhrazeno pro díla produkovaná v řrečtině; v Nizozemí je zase veřejnoprávním stanicím zákonem ukládána povinnost vyhradit $50 \%$ vysílacího času pořadům v holandštině nebo fríštině (v př́ípadě komerčních stanic tento limit činí pouze 40 \%); ve Švédsku musí veřejnoprávní vysílatel SVT věnovat 55 \% svého programového rozpočtu na díla, jejichž producenti mají sídlo ve Švédsku (David Graham and Assoc. Ltd. 2005: 96).

22 Ve Francii ukládá zákon terestrickým, volně přístupným stanicím povinnost vynakládat minimálně 3,2 \% jejich čistého finančního obratu na domácí fillmy; v př́padě placených televizních kanálů je toto minimum stanoveno na $20 \%$. Ve Švédsku či Finsku musí národní stanice také přispívat na vznik národní filmové produkce. V Rakousku jsou vysílatelé zavazováni přispívat do centrálně spravovaného filmového fondu (David Graham and Assoc. Ltd. 2005: 96).

23 Zbylé dva kvadranty v uvedeném modelu (David Graham and Assoc. Ltd. 2005: 98) tvoří Nizozemí, Norsko, Španělsko a Švédsko (flexibilní aplikace Směrnice, ale vysoké dodatečné požadavky) a dále Řecko s Lucemburskem (preskriptivní aplikace Směrnice, avšak nízké dodatečné 


\section{Programové kvóły v kontextu českého televizního trhu}

Od roku 2001, kdy byl přijat současný vysílací zákon, Rada pro rozhlasové a televizní vysílání (jakožto národní regulační orgán) monitoruje implementaci článků 4 a 5 Směrnice TWF (do vysílacího zákona implementovaných v podobě paragrafư 42, 43 a 44) a zveřejňuje výsledky monitorování ve svých výročních zprávách. Data z pěti po sobě jdoucích let dokládají, že všechny čtyři hlavní národní terestrické stanice, kterých se tyto články týkají, zatím vždy vyhověly požadavku naplnit nejméně $50 \%$ vysílacího času evropskou tvorbou. Tento úkol se ukazuje být mnohem jednodušší pro veřejnoprávní Českou televizi, jejíž oba kanály $\check{C} T 1$ i $\check{C} T 2$ pohodlně překračují stanovený limit $(86 \%$ v prípadě $\breve{C} T 1$ a $89 \%$ v př́ípadě $\breve{C} T 2$ $\mathrm{v}$ roce 2006), zatímco její komerční konkurenti se zejména $\mathrm{v}$ počátku dostávali přes dotyčnou hranici s obtížemi (TV Nova ji v roce 2003 překročila jen o 0,8 \%), avšak v posledních několika letech rovněž nevykazují v tomto ohledu žádné zásadní problémy.

Graf 1: Podíl evropské tvorby ve vysílání hlavních českých televizních stanic (v \%)

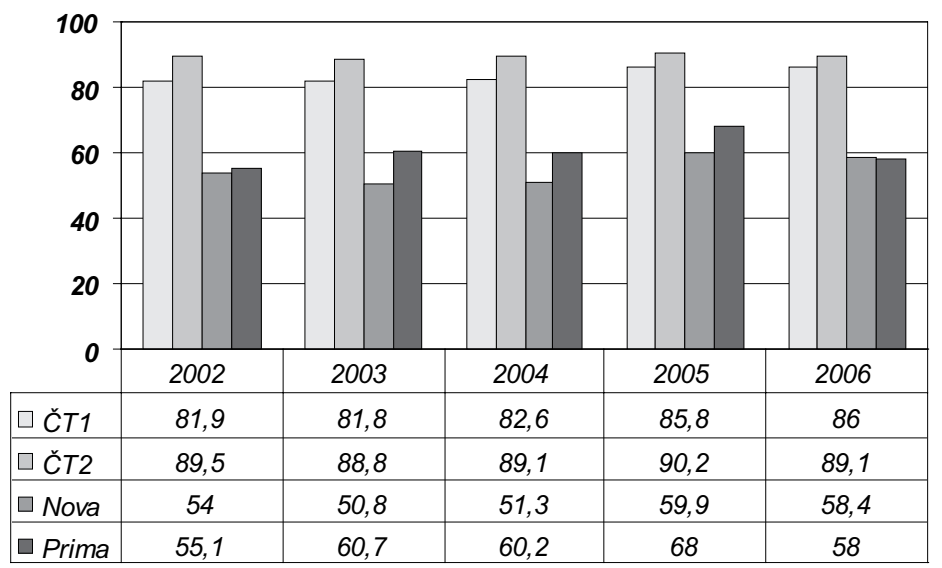

Zdroj: Výroční zprávy Rady pro rozhlasové a televizní vysílání 2002-2006 (http://www.rrtv.cz)

Pokud jde o nezávislou tvorbu, české televizní stanice - s jedinou výjimkou - rovněž doposud vždy zvládaly naplňovat požadovanou $10 \%$ kvótu. Jestliže však v př́ípadě evropských děl vykazovaly zřetelně lepší výsledky veřejnoprávní stanice, v př́ípadě nezávislé tvorby je situace opačná: komerční stanice TV Nova a TV Prima opakovaně zaplňují až třetinu vysílacího času programy pocházejícími od nezávislých producentů, zatímco Česká televize v roce 2004 vykázala u stanice $\breve{C} T 1$ pouze $8,5 \%$ těchto děl (ve zprávě Evropské komisi byl ovšem tento údaj vysvětlen chybnou definicí nezávislého producenta - viz Evropská unie 2006b).

požadavky). Verifikace pozice České republiky v rámci tohoto modelu by nicméně vyžadovala znalost konkrétních metod výpočtu, které uživají autoři modelu; ti bohužel v uvedené studii tyto metody blíže nespecifikují. 
Graf 2: Podíl nezávislé tvorby ve vysilání hlavních českých televizních stanic (v \%)

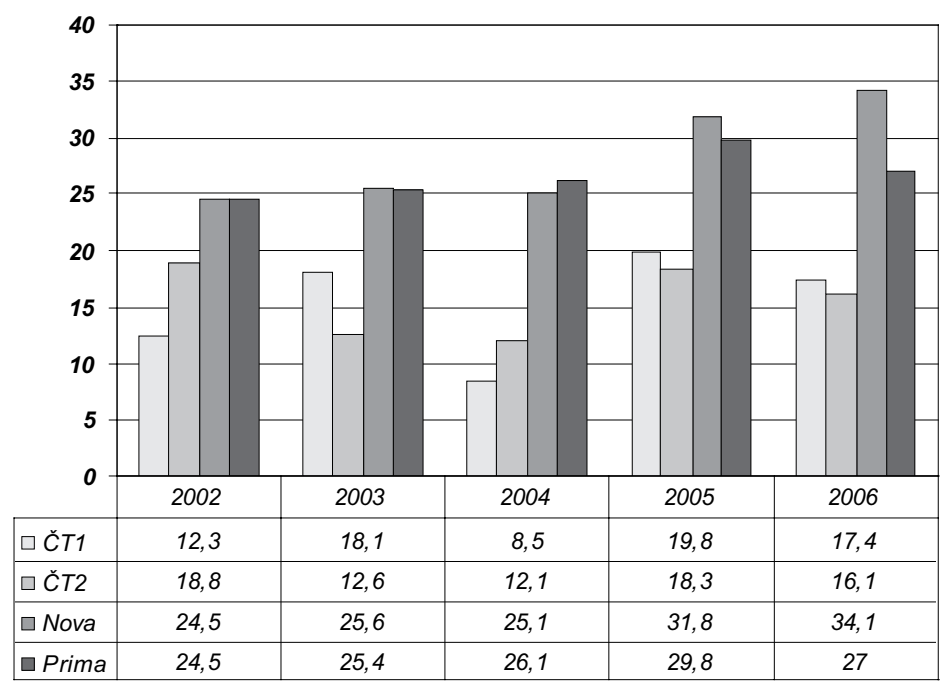

Zdroj: Výroční zprávy Rady pro rozhlasové a televizní vysilání 2002-2006 (http://www.rrtv.cz)

Výše nastíněný obraz bezproblémového uplatňování kvótní politiky na českém televizním trhu se nicméně poněkud zkomplikuje, přidáme-li do hodnocení kabelové a satelitní stanice, které jsou podle textu Směrnice TWF i českého vysílacího zákona rovněž povinny kvóty dodržovat. Ve zprávě Evropské komisi z roku 2004 poskytla RRTV informace o programové struktuře 12 stanic z období mezi 1. květnem 2004 (datum vstupu ČR do EU) a 31. prosincem 2004. Z této zprávy vyplývá, že pět stanic (bez výjimky placené kanály patrící společnosti $H B O$ ) nenaplnilo požadované limity na evropskou produkci, což se promítlo i do celkového průměru ČR, který činil v daném období 49,1%, a poskytl tak Komisi důvod k závěru, že „Česká republika je jediným členským státem, jehož stanice v úhrnu nepřekročily v daném roce průměr 50 \% odvysílané evropské tvorby“ (Evropská unie 2006c: 24). Navzdory proklamovanému odhodlání RRTV ,zahájit dialog s vysílateli za účelem zlepšení situace“ (Evropská unie 2006c: 56) je z výroční zprávy RRTV za rok 2006 zřejmé, že dotyčné placené kanály (zejména $H B O, H B O 2$ a Cinemax) jsou stále značně vzdálené jak limitu na evropskou, tak nezávislou tvorbu. Zatímco v roce 2005 ještě provozovatel poskytl vysvětlení, proč nemohl naplnit požadované kvóty, ${ }^{24} \mathrm{v}$ následujícím roce již žádné vysvětlení zasláno nebylo, ačkoli podíly evropských a nezávislých programů nezaznamenaly žádný podstatný nárůst. Tento př́pad tak dále prohlubuje pochybnosti o skutečné vưli regulačních

24 Důvodem pro neplnění kvótních požadavků je podle provozovatele fakt, že ,evropská díla jsou všeobecně hưřre dostupná“, zejména pokud jde o filmy „kvalitní a komerčně úspěšné“, a také to, že „cena evropských filmů je vyšší než cena americké produkce“ (Rada pro rozhlasové a televizní vysílání 2006: 53-54). 
orgánů vynutit dodržování programových kvót (tato otázka např́klad doposud nikdy nebyla předmětem jednání RRTV, alespoň podle veřejně dostupných zdrojů) ${ }^{25}-$ což je, jak se zdá, obecný problém ve většině zemí EU. ${ }^{26}$

\section{Kulturní preference českého publika: Nadvláda domácích pořadů}

Při pohledu na údaje reprezentující podíl evropských programů na obrazovkách hlavních domácích televizních stanic lze rozumět pozitivnímu hodnocení naplňování kvótní politiky, které obsahuje prozatím poslední výroční zpráva RRTV (viz RRTV 2007). Nicméně bližší prozkoumání údajů z roku 2006, kdy byli vysílatelé Radou poprvé požádáni o poskytnutí informací týkajících se samostatného podílu českých a dalších evropských programů, odhaluje, že většina programů uváděných v kategorii „evropská tvorba“ je čistě domácího původu. Tato skutečnost je mnohem výraznější v případě veřejnoprávních stanic $\check{C} T 1$ a $\check{C} T 2$, kde podíl zahraničních evropských programů činil pouze 8,4 \% (resp. 13,2 \%) v roce 2006, zatímco více než tři čtvrtiny celkového vysílacího času tvořily domácí programy.

Graf 3: Podíl domácích a zahraničních evropských programů ve vysilání hlavních českých televizních stanic ( $\vee \%)$

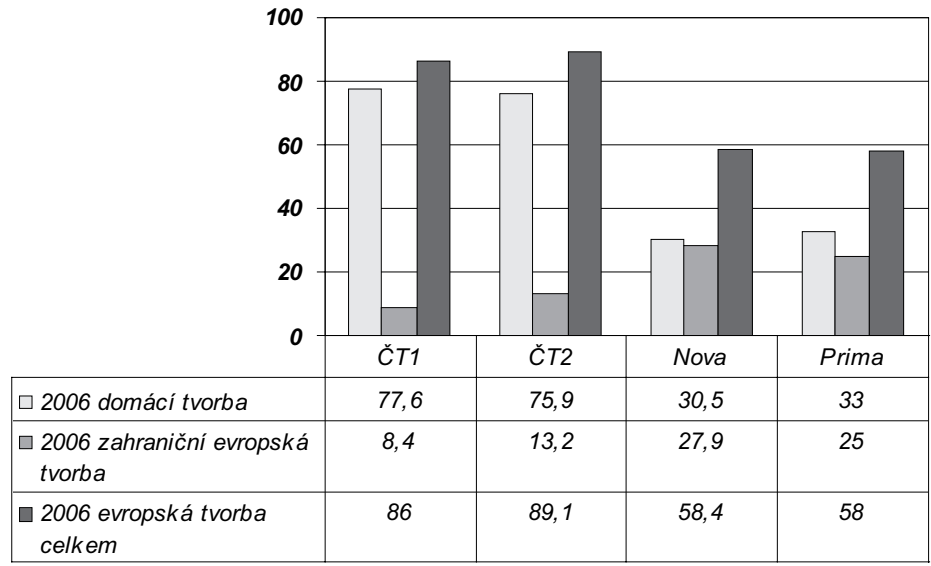

Zdroj: Výroční zprávy Rady pro rozhlasové a televizní vysílání 2002-2006 (http://www.rrtv.cz)

Jak lze vyčíst z grafu 3, komerční stanice vykazují vyváženější proporci české a zahraniční evropské tvorby než televize veřejné služby. Zvláště patrné je to $\mathrm{v}$ př́ipadě $T V$ Nova;

25 Viz zápisy z jednání Rady pro rozhlasové a televizní vysílání dostupné na webových stránkách Rady (http://www.rrtv.cz/cz/dynamic/memo.aspx, cit. 12. 4. 2007).

26 Z rozhovorů se zástupci národních regulačních orgánů (David Graham and Assoc. Ltd. 2005: 93) vyplývá, že jen tři z nich jsou přesvědčeni o tom, že sankce jsou aplikovány „často“; podle dalších osmi se tak děje bud' „někdy“ nebo ,vůbec“. 
u ní je však tato statistika poněkud zkreslena faktem, že tato televize současně vysílá největší množství koprodukované tvorby, a to převážně koprodukcí zahrnujících ne-evropské, ponejvíce americké partnery. ${ }^{27}$

Nerovná pozice domácích a zahraničních evropských programů může být dále dokumentována pomocí údajů o divácké sledovanosti těchto programů. Sekundární analýza dat z peoplemetrového šetření potvrzuje výše diskutovaný celoevropský trend, charakterizovaný dominancí domácích programů nad zahraničními a současně dominancí americké tvorby nad evropskou, pokud k ní nejsou počítány domácí programy. Nepočítáme-li z hlediska sledovanosti relativně marginální kanál $\breve{C} T 2$, lze říci, že na třech hlavních národních pozemských stanicích v České republice domácí programy ovládají hlavní vysílací čas (prime-time, 20.00-23.00) a obvykle také přitahují pozornost největšího počtu diváků. Následující tabulka ukazuje, že zahraniční programy se zřídkakdy vůbec objevují mezi těmi s nejvyšší sledovaností, přičemž v takovém př́padě mají většinou převahu americké programy nad evropskými.

Tabulka 1: Podíl domácí a zahraniční produkce mezi prvními sto programy odvysílanými v hlavním vysílacím čase na třech hlavních českých TV stanicích (vzorek: III, VI, IX, XII/2006)

\begin{tabular}{|c|c|c|c|c|c|c|}
\hline \multirow[t]{2}{*}{$\begin{array}{l}\text { Televizní } \\
\text { stanice }\end{array}$} & \multicolumn{2}{|c|}{ Domácí programy } & \multicolumn{2}{|c|}{$\begin{array}{c}\text { Zahraniční evropské } \\
\text { programy }\end{array}$} & \multicolumn{2}{|c|}{ Americké programy } \\
\hline & $\begin{array}{c}\text { Počet } \\
\text { pořadů } \\
\text { v Top } 100\end{array}$ & $\begin{array}{l}\text { Nejvyšší } \\
\text { umístění } \\
\text { pořadu / } \\
\text { divácká } \\
\text { sledovanost }\end{array}$ & $\begin{array}{l}\text { Počet } \\
\text { pořadů } \\
\text { mezi Top } \\
100\end{array}$ & $\begin{array}{l}\text { Nejvyšší } \\
\text { umístění } \\
\text { pořadu / } \\
\text { divácká } \\
\text { sledovanost }\end{array}$ & $\begin{array}{c}\text { Počet } \\
\text { pořadů } \\
\text { v Top } 100\end{array}$ & $\begin{array}{l}\text { Nejvyšší } \\
\text { umístění } \\
\text { pořadu / } \\
\text { divácká } \\
\text { sledovanost }\end{array}$ \\
\hline С̆T1 & 96 & 1. / $28,5 \%$ & 0 & 0 & 4 & $49 . / 13,7 \%$ \\
\hline Nova & 83 & 1. / $28,3 \%$ & 4 & 41. / $24,4 \%$ & 13 & 58. / 22,3\% \\
\hline Prima & 95 & 1. / 17,8\% & 1 & $80 . / 9,6 \%$ & 4 & $20 . / 14,1 \%$ \\
\hline
\end{tabular}

Zdroj: ATO-Mediaresearch, s.r.o. (http://www.ato.cz)

Legenda: Tabulka zahrnuje pouze programy, které spadaji do definice kvótních požadavků z hlediska vysílacího zákona (drama, fikce, film a talk show).

Rozdíly mezi nejúspěšnějšími domácími, evropskými a americkými programy (jak co do jejich počtu, tak co do hodnot divácké sledovanosti), jsou více než zřetelné. Na veřejnoprávní ČT1 se mezi stovku nejsledovanějších pořadů dostaly jen čtyři zahraniční, všechny přitom pocházejí ze Spojených států amerických (nejvyšší sledovanosti $-13,7$ \% - z nich dosáhl rodinný animovaný film Doba ledová). Statistiky komerční TV Prima jsou velmi

27 Tento údaj se zakládá na autorově vlastní sekundární analýze dat získaných ze čtyřměsíčního vzorku programové skladby a divácké sledovanosti hlavních českých televizních stanic ( $\check{C} T 1$, Nova, Prima; databáze pochází z peoplemetrového šetření ATO-Mediaresearch, s.r.o.) Během těchto čtyř měsíců (březen, červen, záŕí a prosinec 2006) TV Nova odvysílala celkem 217 pořadů v mezinárodní koprodukci (tj. programů, jejichž produkce zahrnuje nejméně dva státy), z nichž 200 zahrnovalo nejméně jednu mimoevropskou zemi, přičemž ve 142 dvou př́ípadech byly touto zemí USA. TV Prima vysílala ve stejném období 59 mezinárodně koprodukovaných pořadů, z nichž polovina zahrnovala neevropskou zemi (většinou opět USA). ČT1 odvysílala 90 koprodukcí, z nichž 55 bylo „čistě evropských“. 
podobné; jediným zahraničním pořadem umístivším se mezi prvními dvaceti byly americké Zoufalé manželky ${ }^{28}$ Relativně nejlépe si vedly evropské pořady na $T V$ Nova-mezi první stovku se dostaly celkem čtyři (nejúspěšnější z nich byl německý krimi seriál Kobra 11), avšak ve srovnání se třinácti pořady původem z USA (reprezentovanými zvláště mezinárodně úspěšnými seriály Ztraceni, Kriminálka Las Vegas či Kriminálka Miami), navíc dosahujícími obecně vyšších ratingů, ani $\mathrm{v}$ tomto prípadě nelze dosti dobře hovořit o úspěšné prezentaci evropské tvorby.

V kontextu těchto údajů (podporovaných ještě následující tabulkou 2 porovnávající nejúspěšnější pořady z žánru fikce) nemůže být pochyb o tom, že výše zmíněný celoevropský trend, charakterizovaný jako „prime-time patří národu“ (EAO 2005: 66) je možno vztáhnout i na popis situace na televizních obrazovkách v České republice. Navzdory snahám EU stimulovat růst pan-evropského televizního trhu a propagovat výměnu audiovizuálních programů dominují české televizní krajině domácí programy, doplňované (zejména mimo hlavní vysílací čas) americkou tvorbou. Vzhledem $\mathrm{k}$ tomu, že domácí programy v tomto vysílacím čase dosahují v přímém srovnání se zahraničními nejvyšších hodnot sledovanosti, lze říci, že chování českého televizního publika je orientováno primárně na národní recepční vzorce, přičemž na obrazovkách hlavních domácích stanic nemá publikum mnoho príležitostí (avšak zdá se, že ani chuti) sledovat tvorbu okolních evropských států. Předpoklad, že v důsledku implementace evropské mediální legislativy „se rozššŕí spektrum ,geografické provenience vysílaných programů oproti současnému stavu“, jak se uvádí v textu vládní „Strategie účinnější státní podpory kultury (kulturní politiky)“ z roku 2001 (Ministerstvo kultury 2001: 38), se tak ukázal jako přespř́liš optimistický.

Z hlediska cílů obsažených v textu Směrnice TWF, jež, jak jsme již zmínili, směšuje kategorie „národní“ a „evropské“" tvorby, nepředstavuje tato situace sama o sobě problém. Nicméně pokud bychom sledovali logiku konceptu „Jednoty v Rozmanitosti“, která se zdá být základem kulturně motivované legitimizace kvótní politiky Směrnice, zůstává otázkou, jakým způsobem české domácí programy přispívají k uchovávání (či proliferaci) evropské kulturní rozmanitosti; či jinými slovy, jaké národně-specifické kulturní reprezentace a hodnoty obohacující Evropu jsou v současnosti reprodukovány skrze domácí televizní pořady. To je nepochybně velmi komplikovaná otázka, jejíž empirické prozkoumání by si vyžadovalo pravděpodobně zcela odlišný metodologický prrístup. Ovšem i stručný pohled na nejpopulárnější televizní programy $\mathrm{v}$ žánru fikce $\mathrm{v}$ roce 2006 vzbuzuje jisté pochybnosti o tom, zda právě česká televizní tvorba představuje významný př́spěvek k evropskému kulturnímu dědictví - jakkoli definovanému. koprodukci. 
Tabulka 2: Pořady z žánru fikce, které dosáhly nejvyšších hodnot sledovanosti na hlavních českých televizních stanicích (vzorek: III, VI, IX, XII/2006)

\begin{tabular}{|c|c|c|c|c|}
\hline Stanice / název programu & $\begin{array}{l}\text { Země } \\
\text { původu }\end{array}$ & Žánr & $\begin{array}{l}\text { Sledovanost } \\
(\%)\end{array}$ & $\begin{array}{c}\text { Podíl na } \\
\text { publiku (\%) }\end{array}$ \\
\hline TV Nova & & & $(15+)$ & $(15+)$ \\
\hline Místo v životě & ČR & Mýdlová opera & 28,3 & 52,3 \\
\hline Pojišfovna štěstí & ČR & Mýdlová opera & 27,5 & 56,8 \\
\hline $\begin{array}{l}\text { Česko hledá SuperStar III } \\
\text { (Pop Idol) }\end{array}$ & ČR & Reality TV & 27 & 50,6 \\
\hline Ordinace v rưžové zahradě & ČR & Mýdlová opera & 25,7 & 49,6 \\
\hline $\begin{array}{l}\text { Výměna manželek } \\
\text { (Wife Swap) }\end{array}$ & ČR & Reality TV & 24,6 & 47,3 \\
\hline \multicolumn{5}{|l|}{ TV Prima } \\
\hline Byl jednou jeden král & ČR & Film & 17,8 & 37,9 \\
\hline Rodinná pouta II & ČR & Mýdlová opera & 17,2 & 31,6 \\
\hline Letiště & ČR & Mýdlová opera & 15,4 & 35,4 \\
\hline $\begin{array}{l}\text { Chůva v akci } \\
\text { (Supernanny) }\end{array}$ & ČR & Reality TV & 13,2 & 27,8 \\
\hline $\begin{array}{l}\text { VyVolení - Finále } \\
\text { (Big Brother) }\end{array}$ & ČR & Reality TV & 12,5 & 33,1 \\
\hline \multicolumn{5}{|l|}{ С̆T 1} \\
\hline Anděl Páně & ČR & Film & 28,5 & 61,8 \\
\hline $\begin{array}{l}\text { StarDance... když hvězdy tančí } \\
\text { (Dancing with the Stars) }\end{array}$ & ČR & Reality TV & 26,8 & 51 \\
\hline Četnické humoresky & ČR & Krimi seriál & 25 & 49,7 \\
\hline Náves & ČR & Mýdlová opera & 22,1 & 43,3 \\
\hline $\begin{array}{l}\text { Hodina pravdy } \\
\text { (Family Feud) }\end{array}$ & ČR & Reality TV & 17,8 & 36,3 \\
\hline
\end{tabular}

Zdroj: ATO-Mediaresearch, s. r.o. (http://www.ato.cz) Legenda: Kurzívou jsou psané původní názvy pořadů

S výjimkou dvou filmů (v obou př́padech pohádek vysílaných během vánočních svátků) jsou nejpopulárnějšími pořady na českých obrazovkách v hlavním vysílacím čase domácí mýdlové opery a reality show, což odpovídá obecnému evropskému trendu, zaznamenanému Evropskou audiovizuální observatoří (EAO 2006). ${ }^{29} \mathrm{~V}$ této souvislosti je tak možné hovořit o strukturální či formální homogenizaci spíše než heterogenizaci či pluralizaci, zejména ve vztahu $\mathrm{k}$ tomu, že většina pořadů z žánru reality $\mathrm{TV}$, které jsou na českých stanicích vysílány, jsou ve skutečnosti globální (a tedy nikoli pouze „evropské“) formáty, které šiř́i jednotný typ zábavy (jakkoli vždy „lokalizovaný“, tj. adaptovaný na místní podmínky) po celém světě

29 Viz též údaje z projektu EurodataTV, dostupné např́iklad na adrese http://www.mediametrie.fr/ webmail/eurodatatvnews06_01_20.htm (cit. 12.4.2007). 
(viz Moran a Keane 2003) a mohou tak být chápány jako jedna z nejviditelnějších současných forem kulturní globalizace. ${ }^{30} \mathrm{~A}$ ačkoli např́íklad domácí mýdlové opery pravděpodobně reflektují a reprodukují národní symbolický repertoár (znaky, symboly, zvyky a stereotypy asociované $\mathrm{s}$ kategorií národa) intenzivněji než pořady typu reality show a mohou být obecně chápány jako „autentičtějšsi “ produkty národních televizních průmyslů, jejich kulturní prínos je jistě možné zpochybňovat stejným způsobem, jako to lze činit $\mathrm{v}$ př́padě reality show.

Je to nicméně právě otázka „kvality“, která je v rámci diskurzu evropské mediální politiky permanentně obcházena. Jak uvádí Phillip Schlesinger, tento diskurz chápe kulturu ve velmi obecném smyslu, když nerozlišuje mezi jejími různými formami („vysoká“, „nízká“ či „populárni““ kultura). Analytické rozlišení mezi „kulturou jako způsobem života“ (zahrnujícím obecně sdílené hodnoty, praktiky a víry určité sociální skupiny) a (užším) chápáním kultury jako „produkce artefaktů, které se mohou stát tržními komoditami““ (Schlesinger 1997: 371-372), se v rétorice tvưrců evropské mediální politiky často směšuje, což vede k tomu, že televizním produktům z oblasti populární kultury je automaticky připisována významná role jak ve vztahu k reprezentaci, tak k reprodukci specifik „způsobu života“ dané národní komunity, díky čemuž si následně „zasluhuji““ ochranu na evropské úrovni. ${ }^{31} \mathrm{~V}$ tomto př́spěvku není dostatek prostoru na hlubší rozbor předpokladů i nedostatků tohoto typu úvah, nicméně samotná myšlenka, že by např́klad tucet různých národních verzí reality show typu Big Brother či Survivor (Trosečnik) měl nějakým způsobem reflektovat či dokonce propagovat rozmanitost evropských kultur, demonstruje podle našeho názoru dostatečně výmluvně krátkozrakost kvótních opatření ve vztahu k proklamovaným kulturním cílům evropské mediální politiky - stejně jako problematické výsledky politiky kombinující čistě ekonomické cíle s kulturně-protekcionistickou rétorikou.

\section{Na cestě k nové směrnici: dále směrem od konceptu Jednoty?}

Jak již bylo naznačeno v úvodu tohoto textu, Evropská komise $\mathrm{v}$ současnosti připravuje zásadní revizi Směrnice TWF, jež by měla být koncem roku 2007 přijata pod názvem Směrnice o audiovizuálních mediálních službách (Directive on Audiovisual Media Services, dále Směrnice AVMS) ${ }^{32}$ Hlavním cílem nové směrnice je aktualizovat legislativu regulující

30 V globalizovaném televizním světě má otázka „původu“ formátů reality TV čím dál menší smysl; nikoli pouze proto, že formáty „záměrně vykuchávají národní prvky“, aby zvýšily své šance proniknout na co nejvíce lokálních televizních trhů (Waisbord 2004: 368), ale také proto, že jsou často samy zpětně transformovány v důsledku početných kopií a odvozených (mnohdy nelicencovaných) verzí, jež cirkulují po celém světě (viz Moran a Keane 2003).

31 Podle Schlesingera ,se jednoduše předpokládá, že konzumace audiovizuálních (kulturních) produktı̊ - jakéhokoli druhu - má významný dopad na kulturu jako způsob života“ (Schlesinger 1997: 372).

32 Plný oficiální název inovované směrnice má znít „Směrnice Evropského parlamentu a Rady 89/552/EHS ze dne 3. ř́jna o koordinaci některých právních a správních předpisů členských států upravujících provozování audiovizuálních mediálních služeb (směrnice o audiovizuálních mediálních službách)“. Členské státy EU budou mít po přijetí nové směrnice 24 měsíců na to, aby uvedly její požadavky do souladu s národní legislativou. 
oblast audiovizuálních médií, a to $\mathrm{v}$ reakci na značný technologický pokrok, který toto pole zaznamenalo v posledních letech (zejména pokud jde o rozšíření nových vysílacích platforem, jako je digitální televize, internet, mobilní telefony atd.). Text návrhu přitom naznačuje, že navzdory opakovaným vyjádřením evropské komisařky Viviane Redingové ohledně potřeby reflektovat a propagovat „,kulturní rozmanitost ${ }^{“ 33}$ je nová legislativa vedena primárně technologickými a ekonomickými pohnutkami, přičemž možným dopadům televizního vysílání na kulturní oblast a na proces evropské integrace se věnuje stejně málo (respektive stejně mělce a nespecifikovaně) jako její předchůdkyně. Z draftu nové Směrnice, zahrnujícího dodatky akceptované Komisí po prvním čtení v Evropském parlamentu (Evropská unie 2007), lze soudit, že na ,povrchu“ zůstává text zakotvený v diskurzu rozmanitosti, když na několika místech zmiňuje kulturní rozmanitost jako specifickou hodnotu, již má nová legislativa ochraňovat. ${ }^{34}$ Pokud srovnáme text původního návrhu Komise (Evropská unie 2005) S verzí přijatou Parlamentem (Evropská unie 2006a), je zřejmé, že většina „kulturních“ zmínek a proklamací byla doplněna poslanci Parlamentu. V prvním recitálu je zavedení nové Směrnice vysvětleno přítomností ,nových technologií“, které vyžadují úpravu regulativního rámce, sloužícího $\mathrm{k}$,zajištění optimálních podmínek pro hospodářskou soutěž, pokud jde o evropské informační technologie a evropská odvětví médií a mediálních služeb“; nicméně Parlament rozšíril formulaci základních cílů Směrnice AVMS o „ohled na kulturní a jazykovou rozmanitost“. Významnou změnu týkající se otázky kulturní rozmanitosti obsahuje Recitál 3, kde původně strohý text Komise „Důležitost audiovizuálních mediálních služeb pro společnosti, demokracii a kulturu odůvodňuje používání zvláštních pravidel pro tyto služby“ je podstatným zpo̊sobem rozšířen, takže první věta zní „Audiovizuální mediální služby jsou stejně tak kulturními statky (goods), jako statky ekonomickými“, což evokuje starou tezi, používanou evropskými politiky v diskuzích okolo vzniku původní Směrnice TWF a ve sporech mezi EU a USA o „kulturní výjimku“v rámci Všeobecné dohody o clech a obchodu (GATT) v letech 1993-1994 (viz Schlesinger 1997, Collins 2002). Toto téma bylo explicitně zmíněno v recitálu 3a, který odkazoval k nedávné rezoluci Parlamentu týkající se jednání o liberalizaci obchodu v katarském Dauhá, jež se vyslovila pro vynětí kulturních produktů $\mathrm{z}$ procesu liberalizace.

Avšak nezávisle na tom, jakým způsobem jsou jednotlivé paragrafy Směrnice AVMS o audiovizuálních mediálních službách legitimizovány, samotný text nepředstavuje žádný pokrok, pokud jde o definici toho, jaká „,kultura“ má být předmětem ochrany, jaká „rozmanitost" má být pěstována a - co je nejpodstatnější - jak by měly být tyto cíle prakticky dosahovány. V této souvislosti je možné novou Směrnici AVMS dokonce chápat jako krok zpět od původních regulativních cílů Směrnice TWF, nebot' i když si ponechává (v nezměněné

33 Viviane Redingová, evropská komisařka pro informační společnost a média, vyjádřila svou starost o otázku kulturní rozmanitosti (a současně přesvědčení, že nová Směrnice napomůže její ochraně) v několika textech a vystoupeních, jež byly zaměřeny na ohlášení a objasnění nadcházející inovace v regulaci audiovizuálních médií; viz Reding (2005a, 2005b, 2006c).

34 Například recitál 47a uvádí, že „kulturní rozmanitost, svoboda vyjadřování a mediální pluralismus [...] patři $\mathrm{k}$ významným aspektům evropského audiovizuálního sektoru, a tudíž i k nezbytným předpokladům demokracie a rozmanitosti““(Evropská unie 2007). 
podobě) kvótní opatření v podobě článků 4 a 5 , zdůrazňuje, že programové kvóty mají platnost pouze v prípadě „lineárních“ služeb (tedy takových, které nabízejí audiovizuální obsah na bázi lineárně seřazených programů, viz např. klasické televizní vysílání), zatímco celá oblast „,nelineárních“ audiovizuálních médií (nabízejících obsah ve formě „katalogu“, ze kterého si konzument vybírá, viz např. video na vyžádání), jejíž vzrůstající význam je uváděn jako jeden z hlavních důvodů revize Směrnice TWF, je ponechána bez jakéhokoliv konkrétního, resp. vynutitelného regulačního opatření. ${ }^{35}$

V recitálu 35 sice Směrnice AVMS uvádí, že tyto druhy mediálních služeb „by měly v př́ípadech, kde je to proveditelné, podporovat tvorbu a šíření evropských děl, a aktivně tak přispívat $\mathrm{k}$ podpoře kulturní rozmanitosti“ a doporučuje, že tato podpora evropské tvorby „může mít např́ílad podobu minimálního podílu evropských děl (přiměřeně k ekonomickému výkonu), minimálního podílu evropských děl v katalozích videa na vyžádání či atraktivní prezentace evropských děl v elektronických programových průvodcích“, avšak tím pokus o „kulturní“ regulaci této oblasti končí. Jestliže - jak jsme v předchozí části tohoto textu dokumentovali - je pro Evropskou komisi značně obtížné zajistit uplatňování relativně pevně stanovených programových kvót, je těžké si představit, že výše citovaná doporučení by měla být provozovateli vysílání i národními regulačními orgány chápána jinak než jako pouhé rétorické cvičení.

\section{Závěrem}

V této stati jsme se pokusili demonstrovat, že na úrovni oficiální rétoriky se evropská audiovizuální politika posunula od zaměření na roli televizního vysílání v reprezentaci společné evropské kultury a pěstování evropské identity, což ji charakterizovalo v počátcích panevropské mediální regulace, směrem k prosazování významu médií pro uchovávání jedinečného charakteru rozličných evropských kultur, a tím k propagaci evropské kulturní rozmanitosti. Tento cíl nicméně zůstává z velké části nespecifikovaný; a jak text Směrnice o Televizi bez hranic, tak aktuální data převzatá z evropských televizních trhů (včetně českého) naznačují, že požadavek kulturní rozmanitosti je v zásadě podř́zen diskurzu národa a podle Evropské komise by měl být realizován prostřednictvím rozkvětu audiovizuálních průmyslů jednotlivých členských států EU. Nová Směrnice o audiovizuálních mediálních službách je zjevně postavena na stejných principech, navzdory tomu, že je Evropskou komisí vyzdvihována coby zásadní inovace $\mathrm{v}$ oblasti evropské mediální regulace.

Jak jsme se snažili v tomto článku ukázat, taková logika vykazuje řadu nedostatků, sahajících od esteticky indiferentního a teritoriálně redukcionistického pojetí kultury, se kterou analyzovaná legislativa zachází pouze ve vztahu ke konkrétnímu národnímu státu (čímž pomíjí širokou jazykovou, etnickou či náboženskou rozmanitost v rámci národních států

35 Jak uvedla Viviane Redingová ve svém projevu na konferenci v Liverpoolu v roce 2005, „Otáz$\mathrm{ka}$, jak postupovat $\mathrm{v}$ př́ípadě nelineárního prostředí, je mnohem kontroverznější. Ačkoli se, jak věřím, můžeme shodnout na tom, že cílem je energický sektor evropské audiovizuální produkce, reflektující rozmanitost našich kultur, je zřejmé, že kvóty na podíl z vysílacího času, jaké stanovuje např́klad článek 4, nepřipadají v úvahu“ (Reding 2005a). 
samotných), až k faktické rezignaci na pokusy změnit národní divácké zvyklosti a umožnit národním televizním publikům konfrontovat své vlastní životní způsoby, hodnoty a kulturní reprezentace - tak, jak je reprodukují televizní pořady - s těmi, které pocházejí z jiných evropských zemí. Nedostatek skutečné rozmanitosti (jak geografické, tak obsahové) na televizních kanálech a selhání Směrnice v pokusu o stimulaci přeshraniční programové výměny byl dále ilustrován $\mathrm{v}$ kontextu aktuální podoby českého televizního trhu, jenž je v současné době ovládán národně zaměřenou programovou nabídkou, jakkoli obsahující nikoli nevýznamný podíl lokálních verzí rozličných globálních televizních formátů. Pouhé číselné statistiky dokládající úspěšné uplatňování programových kvót (přinejmenším u hlavních českých terestriálních stanic) ř́kají jen velmi málo o tom, co diváci skutečně v televizi sledují, a prakticky nic o tom, v jakém smyslu aktuální česká televizní kultura odráží či dokonce posiluje předpokládané evropské kulturní dědictví.

Ačkoli tento př́íspěvek nebyl zpracován jako komparativní analýza a zabýval se - převážně $\mathrm{z}$ důvodu dostupnosti - jen omezeným množstvím dat, dílčí údaje, které zde byly prezentovány, naznačují, že převaha národních programů a národně orientovaných vzorců sledovanosti je společnou charakteristikou evropské televizní scény, což v důsledku vede k audiovizuální „roztřiššěnosti“ Evropy, mnohem spíše než k její unifikaci, a k mediálnímu a diváckému partikularismu, narušovanému pouze americkými seriály a filmy, př́padně (globálními) televizními formáty. Nezdá se být príiliš pravděpodobné, že nadcházející technologická transformace audiovizuálního pole, takzvaná „digitální revoluce“ (Levy 2001), by měla tento trend nějak zásadně zvrátit - mnohem častěji bývá naopak konstatován potenciál nových technologií dále zintenzivnit proces kulturní a sociální fragmentarizace (Murdock 2000). V kontextu těchto vyhlídek je namístě vrátit se k otázkám formulovaným v úvodu této statě, totiž jakým směrem se bude dále vyvíjet evropský integrační projekt a o jaký typ kulturního sebevymezení se bude opírat. Teprve od důkladného znovupromyšlení a zodpovězení těchto otázek se totiž může odvíjet formulace skutečné supranacionální kulturní politiky (k níž, jak zde bylo demonstrováno, Směrnici TWF ani AVMS dost dobře počítat nelze), kterou bude Evropská unie podle Phillipa Schlesingera potřebovat tím naléhavěji, „čím více se [...] začne chovat jako federální politická formace“" (Schlesinger 1997: 371). Je možné, že v podmínkách přetrvávající rezistence národních kultur a identit vůči tlakům globalizace i evropeizace takový pokus nemá př́liš velké šance na úspěch; zda to bude platit i pro generace dnešních dětí, pro něž jsou kosmopolitní kultury, transnacionální média a hybridní identity mnohem přirozenější součástí jejich životních světů než v případě generace jejich rodičů, zůstává prozatím otevřenou otázkou.

\section{Literatura}

Bowman, J. 2006. „The European Union Democratic Deficit: Federalists, Skeptics, and Revisionists.“ European Journal of Political Theory, vol. 5 (2): 191-212.

Bruter, M. 2003. „Winning Hearts and Minds for Europe: The Impact of News and Symbols on Civic and Cultural European Identity.“ Comparative political studies, Vol. 36 (10): $1148-1179$.

Collins, R. 2002. Media and Identity in Contemporary Europe: Consequences of Global Convergence. Bristol: Intellect. 
Dayan, D.; Katz, E. 1992. Media Events: The Live Broadcasting of History. Cambridge: Harvard University Press.

De Bens, E.; de Smaele, H. 2001. „,The Inflow of American Television Fiction on European Broadcasting Channels Revisited.“ European Journal of Communication, Vol. 16 (1): 51-76.

Delanty, G.; Rumford, Ch. 2005. Rethinking Europe: Social Theory and the Implications of Europeanization. London and New York: Routledge.

Delanty, G. 2000. Citizenship in a Global Age. Society, Culture, Politics. Buckingham, Philadelphia: Open University Press.

Downey, J.; Koenig, T. 2006. „Is There a European Public Sphere? The Berlusconi-Schulz Case." European Journal of Communication 21 (3): 165-187.

Eriksen, E. O. 2005. „An Emerging European Public Spere.“ European Journal of Social Theory 8 (3): 341-363.

European Audiovisual Observatory. 2005. Yearbook 2005. Film, Television, Video and Multimedia in Europe, Vol.( 5): Television Channels- Programme Production and Distribution. Strasbourg: European Audiovisual Observatory.

Evropská unie. 1988. Conclusions of the Presidency, European Council, 2 and 3 December. Brussels: European Council.

Evropská unie. 1997a. Treaty of Amsterdam amending Treaty on European Union Establishing the European Communities and Certain Related Acts, signed at Amsterdam, 2 October. Brussels: European Council.

Evropská unie. 1997b. Directive 97/36/EC amending the 1989 'Television without Frontiers' Directive, OJ L 202, 30 July. Brussels: European Commission.

Evropská unie. 2006b. Communication from the Commission to the European Parliament, the Council, the European Economic and Social Committee and the Committee of the Regions: Seventh communication on the application of Articles 4 and 5 of Directive 89/552/EEC ,, Television without Frontiers “, as amended by Directive 97/36/EC, for the period 2003-2004, 14 August. Brussels: European Commission.

Evropská unie. 1989. Směrnice Rady ze dne 3. ř́jna 1989 o koordinaci některých právních a správních předpisů členských států upravujících provozování televizního vysílání (89/552/EHS). Brusel: Evropská komise.

Evropská unie. 1992. Smlouva o Evropské unii (92/C 191/01). Brussels: European Council.

Evropská unie. 2005. Návrh Směrnice Evropského parlamentu a Rady, kterou se měni Směrnice Rady 89/552/EHS o koordinaci některých právních a správních předpisů členských států upravujících provozování televizního vysílání (předložená Komisí). Brusel: Evropská komise.

Fiala, P. 2007. Evropský mezičas: nové otázky evropské integrace. Brno: Společnost pro odbornou literaturu - Barrister \& Principal.

Chalaby, J. 2002. „Transnational Television in Europe: The Role of Pan-European Channels.“ European Journal of Communication, Vol. 17 (2): 183-203.

Chalaby, J. 2006. „American Cultural Primacy in a New Media Order: A European Perspective.“ International Communication Gazette, Vol. 68, s. 33-53.

Kevin, D. 2003. Europe in the Media. Florence: Lawrence Erlbaum Associates. 
Levy, D. A. L. 2001. Europe's Digital Revolution. Broadcasting Regulation, the EU and the Nation State. London and New York: Routledge.

Machill, M.; Beiler, M.; Fischer, C. 2006. „Europe-Topics in Europe’s Media: The Debate about the European Public Sphere: A Meta-Analysis of Media Content Analysis.“ European Journal of Communication, Vol. 21 (1): 57-88.

Moran, A.; Keane, M. (eds.) 2003. Television across Asia: Television Industries, Programme Formats and Globalisation. RoutledgeCurzon: London.

Murdock, G. 2000. „Digital Futures: European Television in the Age of Convergence.“ In J. Wieten, G. Murdock, P. Dahlgren (eds.) Television Across Europe: A Comparative Introduction. Sage: London.

O’Connell, S. P. 1996. „Television Without Frontier: The European Union's Continuing Struggle for Cultural Survival.“ Case Western Reserve Journal of International Law, Vol. 28, (2): 501-530.

Peter, J.; de Vreese, C. H. 2004. „In Search of Europe. A Cross-National Comparative Study of the European Union in National Television News. " Harvard Journal of Press/ Politics, Vol. 9 (4): 3-24.

Sassatelli, M. 2002. „Imagined Europe. The Shaping of a European Cultural Identity through EU Cultural Policy.“ European Journal of Social Theory, Vol. 5(4): 435-451.

Schlesinger, P.; Fossum, E. J. 2005. „The European Union and the Public Sphere: A Communicative Space in the Making?" Paper presented at the Concluding Conference of the CITADEL Project Law and Democracy in Europe's Post-National Constellation, September 2005, Firenze, Italy, s. 22-24.

Schlesinger, P. 1991. Media, State and Nation: Political Violence and Collective Identities. London: Sage.

Schlesinger, P. 1997. „From Cultural Defense to Political Culture: Media, Politics and Collective Identity in the European Union." Media, Culture \& Society, Vol. 19, s. 369 - 391.

Silj, A. 1989. East of ,Dallas “: The European Challenge to American Television. British Film Institute.

Štětka, V. 2003 „Evropa na obrazovkách: Audiovizuální politika a konstrukce evropské identity.“ In V. Štětka, J. Volek (eds.) Média a realita 04. Sborník praci Katedry mediálních studii a žurnalistiky FSS MU Brno. Brno: Masarykova univerzita.

Trenz, H. J. 2004. „Media Coverage on European Governance: Exploring the European Public Sphere in National Quality Newspapers.“" European Journal of Communication, Vol. 19 (3): 291-319.

Tunstal, J.; Machin, D. 1999. The Anglo-American Media Connection. Oxford: Oxford University Press.

Van Steeg, M. 2002. „Rethinking the Conditions for a Public Sphere in the European Union.“ European Journal of Social Tudory, Vol. 5 (4): 499-519.

Waisbord, S. 2004. „McTV: Understanding the Global Popularity of Television Formats.“ Television and New Media, Vol. 5, s. 359-383.

Wheeler, M. 2004. „Supranational Regulation, Television and the European Union.“ European Journal of Communication, Vol. 19 (3): 349-369. 


\section{Internetové zdroje}

Česká republika (2001). 231/2001 Sb. Zákon ze dne 17. května 2001 o provozování rozhlasového a televizního vysílání a o změně dalších zákonů. [citováno dne 6. 4. 2007]. Dostupný z: http://www.rrtv.cz/cz/static/zakony/pdf/231-2001.pdf.

David Graham and Associates Limited (2005). Impact Study of Measures (Community and National) Concerning the Promotion of Distribution and Production of TV Programmes Provided for Under Article 25(a) of the TV Without Frontiers Directive. Final Report Prepared by David Graham and Associates Limited for The Audiovisual, Media and Internet Unit Directorate-General Information Society and Media European Commission, 24 May 2005. [citováno dne 12. 4. 2007]. Dostupný z: http://ec.europa.eu/avpolicy/docs/library/ studies/finalised/4-5/27-03-finalreport.pdf.

Evropská unie. 2006a. European Parliament legislative resolution on the proposal for a directive of the European Parliament and of the Council amending Council Directive 89/552/EEC on the coordination of certain provisions laid down by law, regulation or administrative action in Member States concerning the pursuit of television broadcasting activities ((COM(2005)0646 - C6-0443/2005 - 2005/0260(COD)). [citováno dne 2. 4. 2007]. Dostupný z: http://www.europarl.europa.eu/sides/getDoc.do?pubRef=-//EP// $\mathrm{TEXT}+\mathrm{TA}+\mathrm{P} 6-\mathrm{TA}-2006-0559+0+\mathrm{DOC}+\mathrm{XML}+\mathrm{V} 0 / / \mathrm{EN} \&$ language $=\mathrm{EN}$.

Evropská unie. 2006c. Background documents to the Communication from the Commission to the European parlament, the Council, the European Economic and Social Committee and the Committee of the Regions: Seventh communication on the application of Articles 4 and 5 of Directive 89/552/EEC ,Television without Frontiers “, as amended by Directive 97/36/EC, for the period 2003-2004, 14 August. Brussels: European Commission.

Evropská unie. 2007. Draft Audiovisual Media Services Directive. Consolidated text, including EP First Reading amendments accepted in full and the amended Commission proposal. Non-binding working document, March. [citováno dne 2. 4. 2007]. Dostupný z: http://ec.europa.eu/avpolicy/docs/reg/modernisation/proposal_2005/avmsd_cons_ amend_0307_en.pdf

Ministerstvo kultury ČR. 2001. Kulturní politika. Praha 2001. [citováno dne 4. 4. 2007]. Dostupný z: http://www.mkcr.cz/assets/ministerstvo/KP.doc.

Nenova, M. B. 2007. The Reform of the EC Audiovisual Media Regulation: Television without Cultural Diversity. NCCR Trade Working Paper. [citováno dne 8. 4. 2007]. Dostupný z: http://www.nccr-trade.org.

Rada pro rozhlasové a televizní vysílání. (2006). Zpráva o stavu vysílání a činnosti Rady pro rozhlasové a televizní vysílání za rok 2005. [citováno dne 6. 4. 2007]. Dostupný z: http:// www.rrtv.cz/cz/files/zpravy/vz05RRTVweb.pdf.

Rada pro rozhlasové a televizní vysílání. (2007). Zpráva o stavu vysilání a činnosti Rady pro rozhlasové a televizní vysílání za rok 2006. [citováno dne 6. 4. 2007]. Dostupný z: http:// www.rrtv.cz/cz/files/zpravy/VZ2006_070220_web.pdf.

Reding, V. 2005a. Better Regulation for Europe's Media Industry: the Commission's Approach. Audiovisual Conference - Between Culture and Commerce, Liverpool, 22 September 2005. [citováno dne 12. 4. 2007]. Dostupný z: http://europa.eu/rapid/pressReleasesAction. do? reference $=\mathrm{SPEECH} / 05 / 532 \&$ format $=$ HTML\&aged $=0 \&$ language $=\mathrm{EN} \&$ guiLanguage $=\mathrm{fr}$. 
Reding, V. 2005b. Europe, the media and European media policy. Speech given at the Congress of the Federal Association of German Newspaper Publishers, Berlin, 26 September 2005. [citováno dne 12. 4. 2007]. Dostupný z: http://europa.eu/rapid/pressReleasesAction.do? reference $=$ SPEECH $/ 05 / 552 \&$ format $=$ HTML\&aged $=0$ \&language $=E N \&$ guiLanguage $=$ fr.

Reding, V. 2005c. New EU Rules for a Convergent Multi-Media World: the need for a ,LightTouch". IIC and Chatham House 36th annual conference, London, 10 October 2005. [citováno dne 12. 4. 2007]. Dostupný z: http://europa.eu/rapid/pressReleasesAction.do? reference $=\mathrm{SPEECH} / 05 / 590 \&$ format $=\mathrm{HTML} \&$ aged $=0$ \&language $=\mathrm{EN} \&$ guiLanguage $=\mathrm{fr}$.

\section{Autor}

Václav Štětka působí od roku 2006 jako odborný asistent na Katedře mediálních studií a žurnalistiky Fakulty sociálních studií MU. Vystudoval sociologii a mediální studia na FSS MU a historii na FF MU. Odborně se věnuje především problematice sociálně-integračních funkcí masových médií v období pozdní modernity a v kontextu procesů globalizace a evropské integrace.

Kontakt: stetka@fss.muni.cz 